\title{
BUDAPEST NAPI KÖZÉPHŐMÉRSÉKLETÉNEK ENERGETIKAI CÉLÚ VIZSGÁLATA
}

\author{
Dian Csenge $^{(1)}$ (D), Talamon Attila ${ }^{(2)}$ (D), Bartholy Judit ${ }^{(1)}$ (D), Pongrácz Rita ${ }^{(1)}$ \\ (1) ELTE Meteorológiai Tanszék, 1117 Budapest, Pázmány Péter sétány 1/A. \\ ${ }^{(2)}$ Energiatudományi Kutatóközpont, 1121 Budapest, Konkoly-Thege Miklós út 29-33. \\ e-mail: dian.csenge@caesar.elte.hu, talamon.attila@energia.mta.hu,bartholy@caesar.elte.hu, \\ prita@nimbus.elte.hu
}

\section{Bevezetés}

Az ELTE Meteorológiai Tanszékén évtizedek óta folynak városklimatológiai kutatások. Ezek főként a beépített városi területek és a külvárosi területek között kialakuló hőmérséklet különbséget, a városi hősziget jelenségét vizsgálták (Oke, 1973). A hősziget-intenzitás elsődlegesen léghőmérséklet méréseken alapul, abból származtatható az intenzitás. A nemzetközi (Klysik \& Fortuniak, 1999; Beranová \& Huth, 2005; Bokwa et al., 2018) és hazai szakirodalomban (Gál et al., 2016; Dian et al., 2019) egyaránt számos kutatás foglalkozik a klasszikus értelemben vett városi hőszigettel. A másik vizsgálati módszer a müholdas adatokon alapuló hősziget-intenzitás elemzések (Voogt \& Oke, 2003; Pongrácz et al., 2010; Schwarz et al., 2011).

A hősziget-intenzitás mellett egyre fontosabbak lesznek az egyéb városklimatológiai kutatások, például a hőterhelés (Bokwa et al., 2019), valamint az energetikai célú vizsgálatok. Az energiafogyasztás kb. 40\%-át az épületek teszik ki, melyek a városokban értelemszerüen koncentráltan vannak jelen. Az épület energetikában különösen fontos szerepe van az időjárásnak, hiszen a komfortos beltéri környezet biztosításához szükséges energia nagymértékben függ a kültéri környezet állapotától, elsősorban a hömérséklettől. Éppen ezért a fütési és hütési berendezések tervezésénél a legfontosabb müszaki paraméterek meghatározásakor figyelembe veszik az átlagos napi középhőmérsékleteket. A fütési és hütési idény szintén fontos része az épület energetikának, azonban ezen időszakok kezdetére és végére többféle definíció is létezik. A 157/2005. (VIII.15.) Kormányrendelet ${ }^{1}$ 3. mellékletének 2.1.7. pontja alapján a fütési időszak: az év szeptember 15. napja és a következő év május 15. napja közötti időszak. A FÖTÁV Zrt. ${ }^{2}$ ezt három szakaszra osztja: előfütési időszak (szeptember 15. - október 14.), fütési időszak (október 15. - április 15.) és utófütési időszak (április 16. - május 15.). Emellett számos nem hivatalos definíció létezik, melyek különböző hőmérsékleti küszöbértékekhez rögzítik a fütési idény kezdetét, illetve végét. A fütési idényen kívüli időszakot nevezzük hütési idénynek.

Legújabb, városklímával kapcsolatos kutatásunk célja az épület energetikát befolyásoló meteorológiai, éghajlati változások elemzése, a fütési és hütési idény hőmérséklet alapú vizsgálata több magyar nagyvárosra vonatkozóan. Ebben a tanulmányban az első eredményeket mutatjuk be Budapestre.

\section{Felhasznált adatok}

Épület energetikában a fütési és hütési berendezések müszaki paramétereinek meghatározásához figyelembe veszik a napi külső középhőmérsékletet. Az OMSZ honlapjáról ${ }^{3}$

\footnotetext{
${ }^{1}$ 157/2005. (VIII. 15.) Kormányrendelet: https://net.jogtar.hu/jogszabaly?docid=A0500157.KOR

${ }^{2}$ FÖTÁV: http://www.fotav.hu/lakossagi-ugyfelek/kozos-kepviseletek-kepviselok-reszere/uzemviteli-megallapodas

${ }^{3}$ OMSZ: https://www.met.hu/eghajlat/magyarorszag_eghajlata/eghajlati_adatsorok/
} 
ingyenesen letölthető öt magyar nagyváros (Budapest, Debrecen, Szeged, Pécs és Szombathely) különböző meteorológiai változóra vonatkozó napi adatsora (nevezetesen: középhőmérséklet, maximum- és minimumhőmérséklet, csapadékösszeg, csapadék fajtája, napfénytartam napi összege) 1901-2010 időszakra. Ezek közül az itt bemutatandó elemzésben Budapest napi középhőmérsékleti adatsorát alkalmaztuk.

\section{Eredmények}

Az energetikai tervezésnél (pl. Talamon, 2014) fontos figyelembe venni az adott területen jellemző napi középhőmérséklet szélsőértékeit, melyek kijelölik azt a hőmérsékleti intervallumot, amire fel kell készíteni az épületeket. Értelemszerüen a fütési szezonban a hideg szélsőségekre kell figyelni, míg a hütési időszakban a meleg szélsőségek az irányadók. Elemzésünkben mindkét irányban kitérünk az extrémumokra. Elsőként a hideg szélsőségeket mutatjuk be az 1. ábrán.

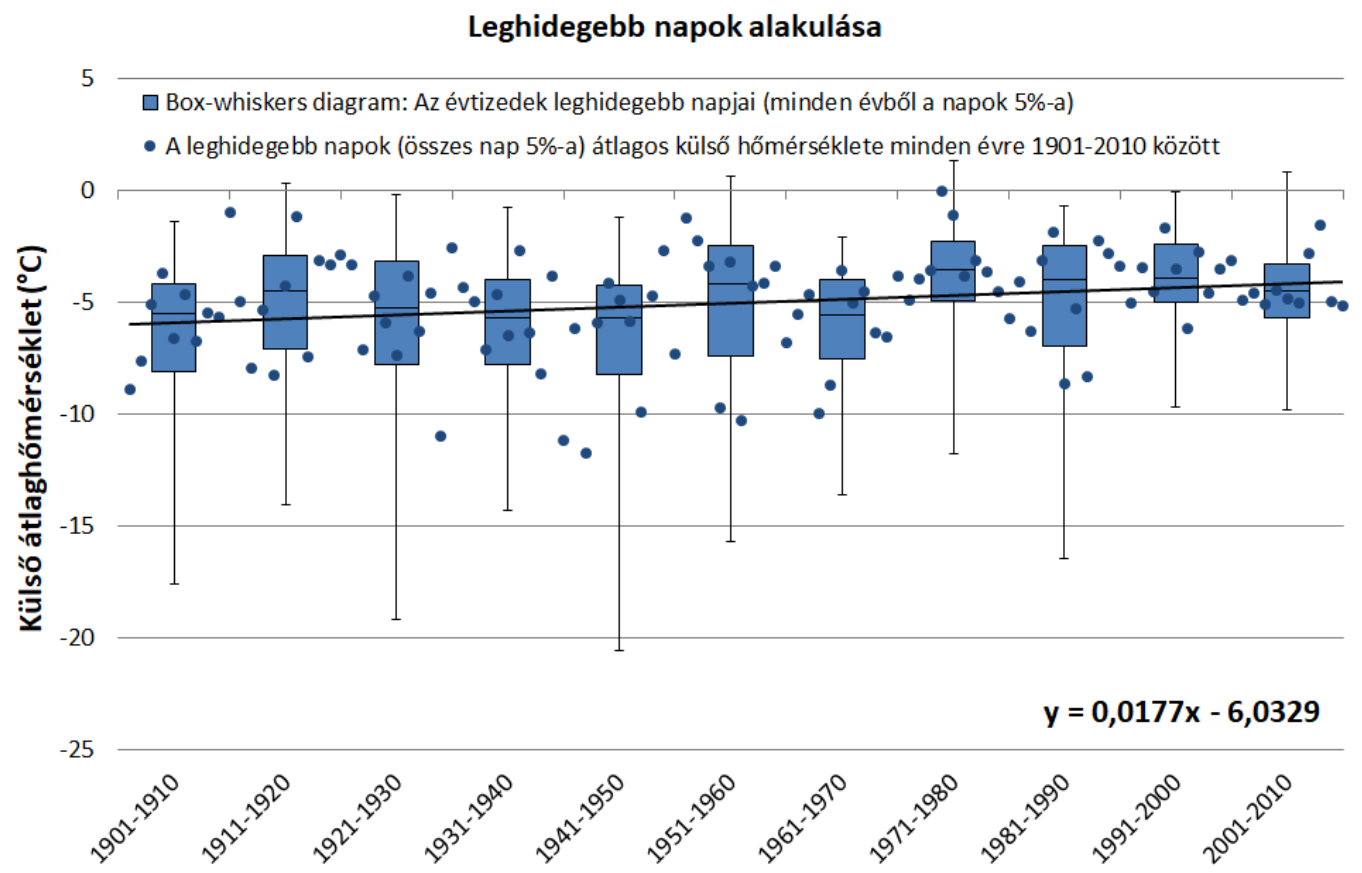

1. ábra: Minden év leghidegebb 18 napja (5\%) évtizedes bontásban box-whiskers diagramon (minimum, alsó kvartilis, medián, felső kvartilis, maximum) és évenként a 18 nap átlaga (kék pontok), valamint az erre illesztett lineáris trend.

Az elemzés során minden évben kiválasztásra kerültek a leghidegebb napok, mégpedig a teljes év 5\%-a, azaz 18 nap. Ezeket évtizedenkénti bontásban box-whiskers diagram ábrázolja. Továbbá minden évben a 18 leghidegebb nap átlaga is megjelenik egy-egy pontként, melyek 110 éves teljes idősorára illesztett lineáris trend is látható az ábrán. A box-whiskers eloszlások alapján megállapítható, hogy a hideg napok széles intervallumban mozognak egyegy évtizeden belül, akár a $20^{\circ} \mathrm{C}$-ot is elérheti a minimum és maximum közötti különbség. $\mathrm{Az}$ átlagosan leghidegebb napok idősorára illesztett lineáris trend alapján egyértelmüen melegedés figyelhető meg Budapesten (mértéke: $1,77^{\circ} \mathrm{C} /$ év$^{\prime}$ század). A leghidegebb napok ezen melegedését érdemes figyelembe venni a fütési berendezések tervezése során. Jól látható, hogy a 110 év első felében fordultak elő gyakrabban alacsonyabb értékek. Az évszázad közepén $-20{ }^{\circ} \mathrm{C}$ alatti napi középhőmérsékletet is regisztráltak Budapesten. Ezzel szemben 1970 óta az évtizedek medián értéke magasabb, azaz az évek leghidegebb 5\%-ának 
fele $-5^{\circ} \mathrm{C}$ fölé esik. A változékonyság mérséklődése is megfigyelhető: az utolsó két évtizedben már csak $10-11^{\circ} \mathrm{C}$-os intervallumba estek a leghidegebb napok, míg korábban többször láthatunk csaknem $20^{\circ} \mathrm{C}$-ot elérő jóval tágabb évtizedes intervallumot is (pl. az 1920-as vagy az 1940-es években).

Ugyanezt a módszertant alkalmaztuk a napok legmelegebb 5\%-ára vonatkozóan (2. ábra). Jól látszik, hogy a meleg napok sokkal szúkebb intervallumban mozognak, mint a hideg napok; legfeljebb $10^{\circ} \mathrm{C}$ a különbség a maximum és minimum között egy-egy évtizedben. A megfigyelhető melegedő tendencia kicsit nagyobb mértékü $\left(1,84^{\circ} \mathrm{C} /\right.$ évszázad). A meleg napok esetén viszont nem mutatkozik az évszázad végére intervallum szükülés az eloszlás teljes terjedelmében, éppen ellenkezőleg. Ez egybevág a klímaváltozás hatására megnövekvő meleg extrémumok, a hőhullámok gyakoribbá válásával (Lakatos \& Bihari, 2011; Göndöcs et al., 2018).

Legmelegebb napok alakulása

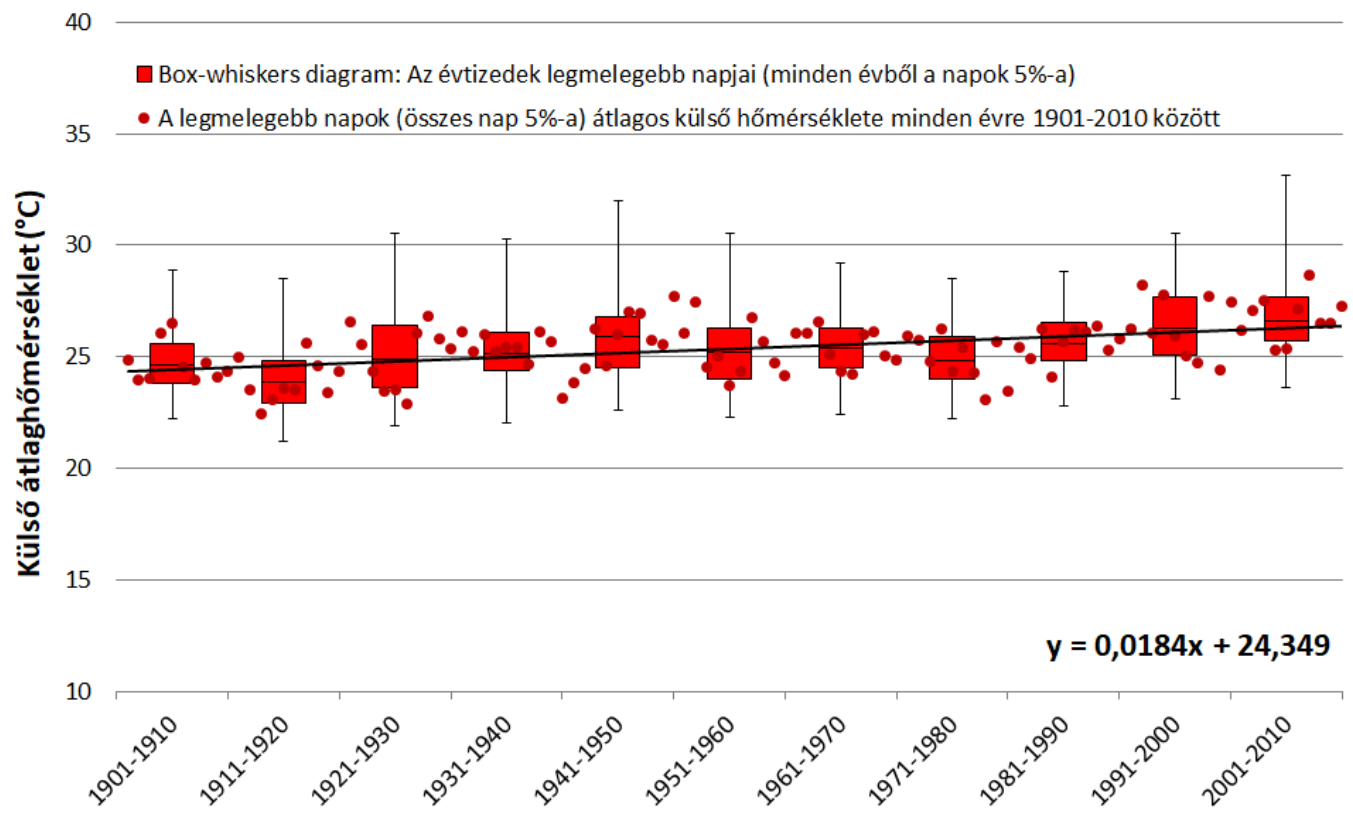

2. ábra: Minden év legmelegebb 18 napja (5\%) évtizedes bontásban box-whiskers diagramon (minimum, alsó kvartilis, medián, felső kvartilis, maximum) és évenként a 18 nap átlaga (piros pontok), valamint az erre illesztett lineáris trend.

Az elemzés következő lépéseként minden évben sorrendbe rendeztük a napokat a leghidegebbtől a legmelegebbig, majd ezeket évtizedenként átlagoltuk, így megkapjuk a hőmérsékleti adatsorok tartamdiagramját. A 3. ábrán öt kiválasztott évtized tartamdiagram görbéje, valamint a teljes 110 éves átlag látható. Két évtizedet mutat be a diagram a vizsgált időszak elejéről (1901-1910, 1911-1920), egyet a közepéröl (1951-1960), valamint az utolsó két évtizedet (1991-2000, 2001-2010). Az eredmények azt jelzik, hogy a hideg napok esetén jóval kisebb a különbség az évtizedes átlagok között, míg a meleg napoknál az évszázad végén akár $3{ }^{\circ} \mathrm{C}$ is lehet a különbség. Az évszázad elején végig a 110 éves átlag alatt maradt a tartamgörbe, míg az évszázad végére már fölé került. A fütés szempontjából fontosabb hideg napok esetén átlagosan 45 napon volt fagypont alatt a napi középhömérséklet, ami összességében az év $12 \%$-át teszi ki. 
Dian Cs., Talamon A., Bartholy J., Pongrácz R.:

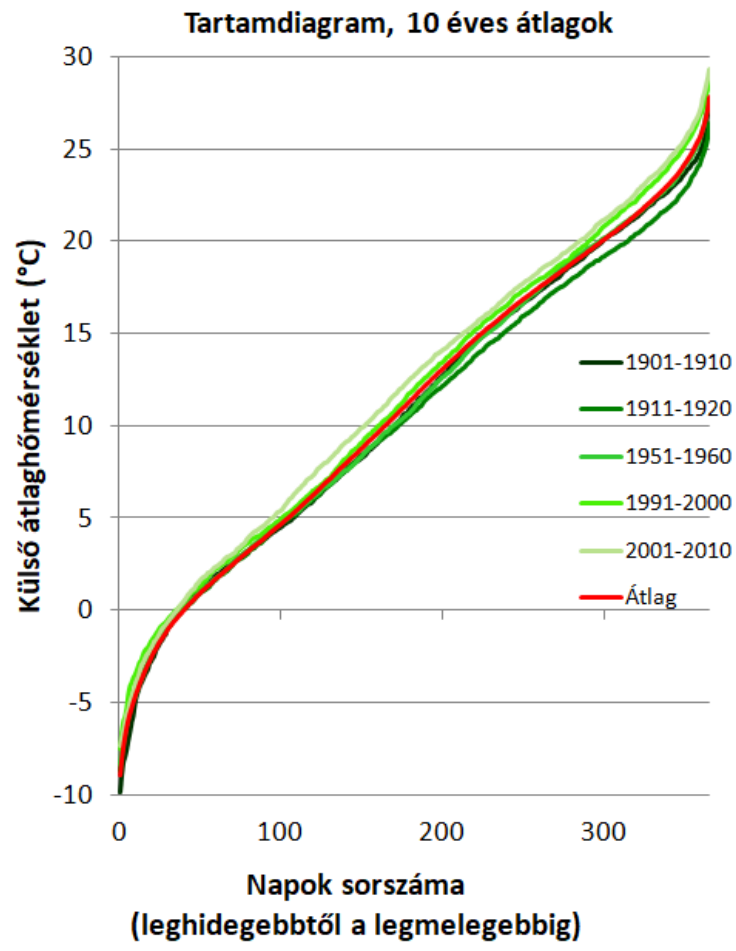

3. ábra: A vizsgált időszak elejére, közepére és végére, valamint a 110 év átlagára vonatkozó tartamdiagramok. A leghidegebb naptól a legmelegebb napig évenként rendezett napi középhőmérsékletek átlagai, az OMSz budapesti állomásának adatsora alapján.

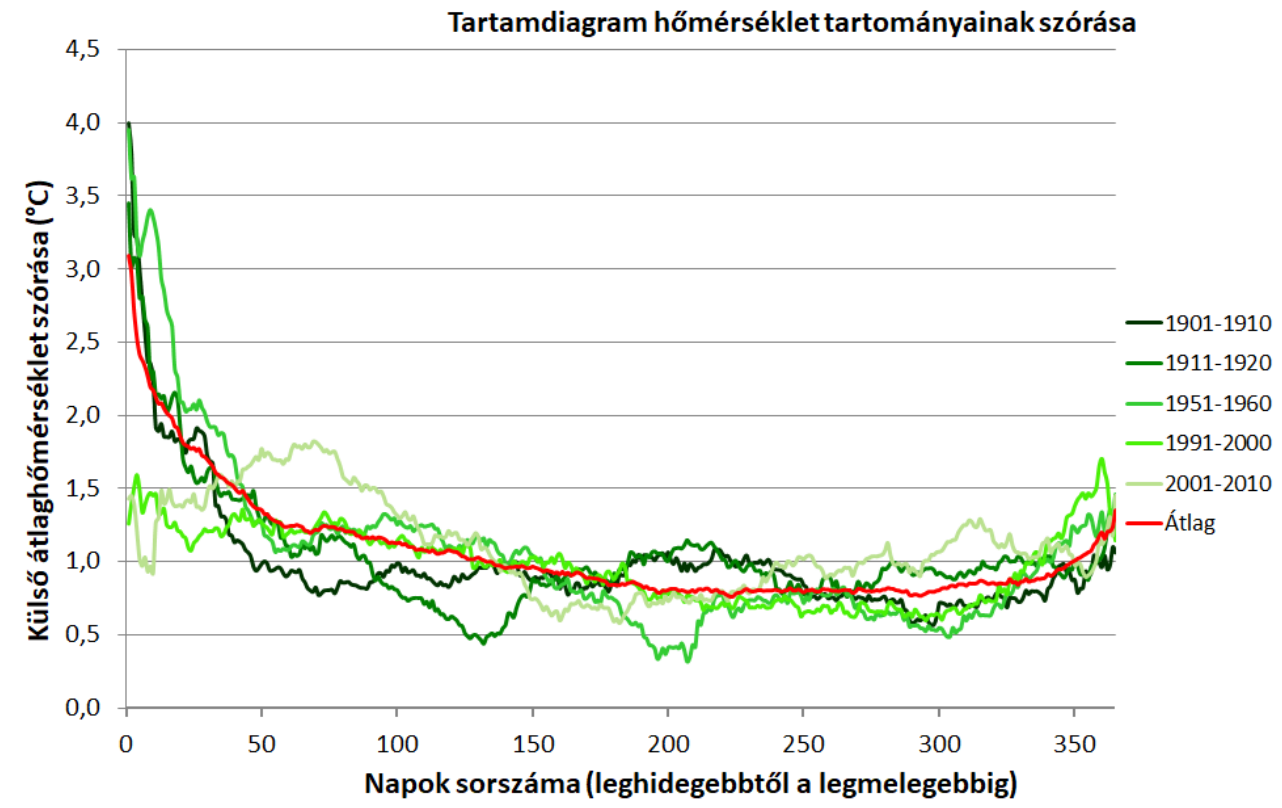

4. ábra: A vizsgált időszak elejére, közepére és végére, valamint a 110 év átlagára vonatkozó tartamdiagramokhoz tartozó hőmérsékleti szórások. A leghidegebb naptól a legmelegebb napig évenként rendezett átlagos napi középhőmérsékletek évtizedenkénti szórása, az OMSz budapesti állomásának adatsora alapján.

A 4. ábra a tartamgörbe hőmérsékleti tartományaihoz tartozó évtizedes átlagos szórásokat mutatja be a kiválasztott időszakokra vonatkozóan. A hideg napoknál a box-whiskers diagramon (1. ábra) látható volt, hogy az évtizedes átlagos hőmérsékletek között kicsi a különbség, 
ezzel szemben az átlagos szórás jóval nagyobb. A 110 év átlagos szórása hideg napok esetén eléri a $3{ }^{\circ} \mathrm{C}$-ot, sőt, a 20. század elején még akár $4{ }^{\circ} \mathrm{C}$-os szórás is elöfordult. Az évszázad elején és közepén még a 110 éves átlaghoz közeli szórások jellemzők a hideg napoknál, míg az utolsó két vizsgált évtizedben jóval alacsonyabbak $\left(1-1,5{ }^{\circ} \mathrm{C}\right.$ között). Az év legnagyobb részében szintén $1-1,5^{\circ} \mathrm{C}$ között alakultak a szórások. A legmelegebb napoknál pedig egy kisebb másodmaximum mutatkozik, ahol a 110 éves átlag is eléri a $1,5^{\circ} \mathrm{C}$-ot. A téli nagy szórások miatt nehézkes a fütési berendezések tervezése, a nyári kisebb szórás viszont kedvezőbb tervezhetőséget biztosít a hütési berendezésekre vonatkozóan.

Végül a kiválasztott évtizedek és a teljes 110 év empirikus sürüségfüggvénye látható a 6. ábrán, azaz az egyes napi középhőmérsékletek $\left(-10^{\circ} \mathrm{C}\right.$ és $+35^{\circ} \mathrm{C}$ között) éves előfordulási gyakorisága. A görbékröl leolvasható, hogy $2-3^{\circ} \mathrm{C}$, illetve $20^{\circ} \mathrm{C}$ körül van egy-egy csúcs a gyakoriságban. A legnagyobb változékonyság a $0-22{ }^{\circ} \mathrm{C}$ tartományban mutatkozik az egyes évtizedek között. A magas hőmérsékletek esetén az utolsó két évtizedben egyértelmüen nagyobb volt a gyakoriság, mint az évszázad elején és végén, valamint $2-3{ }^{\circ} \mathrm{C}$-kal magasabb hőmérsékletek is előfordultak, mint korábban. A hideg tartományban kevésbé azonosítható egyértelmü különbség a görbék között. Tehát a nyári időszakban stabilabb változás látszik, mint télen; ezért az energetikai tervezhetőséget könnyebb a meleg napokra alapozni.

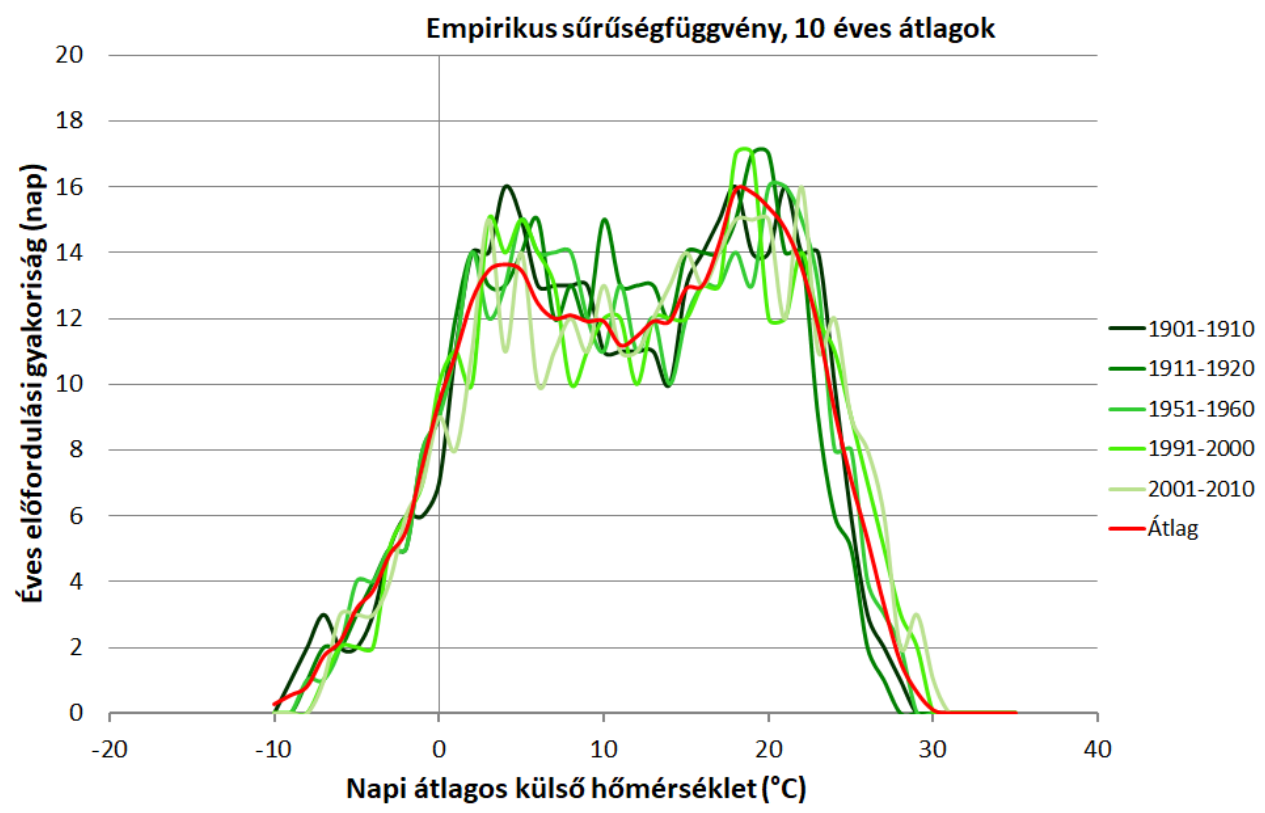

5. ábra: A vizsgált időszak elejére, közepére és végére, valamint a 110 év átlagára vonatkozó empirikus sürüségfüggvények, azaz az egyes hőmérsékleti értékekhez tartozó éves előfordulási gyakoriságok, az OMSz budapesti állomásának adatsora alapján.

\section{Összefoglalás}

Az épület energetika szempontjából fontos hőmérsékleti paraméter a napi középhőmérséklet. Budapest 110 éves állomási adatsorát vizsgálva megállapítható, hogy a regionális melegedés egyértelmüen detektálható a hideg és meleg extrémumokban egyaránt. Tehát egyrészt az egyes évtizedekre vonatkozó legmelegebb napok átlagos hőmérséklete magasabb a vizsgált időszak végén, mint az elején. Másrészt a téli, hideg napok szélsőségei az elmúlt 110 évben mérséklődtek, de összességében nagyobb szórásúak, mint a magas hőmérsékletü meleg napok. Mindezek arra utalnak, hogy a fütésre vonatkozó müszaki és gazdasági tervezés nagyobb kihívásoknak néz elébe, mint a hütési rendszerek esetén. 
A megkezdett kutatás folytatásaként további terveink között szerepel több hazai nagyváros hőmérsékleti adatsorának elemzése az energetikai szempontok figyelembe vételével, valamint a fütési és hütési idény változásának részletesebb vizsgálata hőmérséklet alapú megközelítéssel.

\section{Köszönetnyilvánítás}

Kutatásainkat az OTKA K-120605 és K-129162 számú projektje, valamint az Emberi Erőforrások Minisztériuma az ELTE Kiválósági Program (projektszám: 783-3/2018/FEKUTSRAT) keretében támogatta.

\section{Hivatkozások}

Beranová, R., Huth, R., 2005: Long-term changes in the heat island of Prague under different synoptic conditions. Theoretical and Applied Climatology, 82: 113-118. https://doi.org/10.1007/s00704-004-0115-y

Bokwa, A., Dobrovolný, P., Gál, T., Geletič, J., Gulyás, Á., Hajto, M.J., Holec, J., Hollósi, B., KielarI, R., Lehnert, M., Skarbit, N., Štastný, P., Švec, M., Unger, J., Walawender, J.P., Žuvela-Aloise, M., 2018: Urban climate in Central European cities and global climate change. Acta Climatologica, 51-52: 7-35. https://doi.org/10.14232/acta.clim.2018.52.1

Bokwa, A., Geletič, J., Lehnert, M., Žuvela-Aloise, M., Hollósi, B., Gál, T., Skarbit, N., Dobrovolný, P., Hajto, M.J., Kielar, R., Walawender, J.P., Št’astný, P., Hole, J., Ostapowicz, K., Burianová, J., Garaj, M., 2019: Heat load assessment in Central European cities using an urban climate model and observational monitoring data. Energy \& Buildings, 201: 53-69. https://doi.org/10.1016/j.enbuild.2019.07.023

Dian, Cs., Pongrácz, R., Incze, D., Bartholy, J., Talamon, A., 2019: Analysis of the urban heat island Intensity based on air temperature measurements in a renovated part of Budapest (Hungary). Geographica Pannonica, 23(4): 277-288 https://doi.org/10.5937/gp23-23839

Gál, T., Skarbit, N., Unger, J., 2016: Urban heat island patterns and their dynamics based on an urban cli-mate measurement network. Hungarian Geographical Bulletin, 65(2): 105-116. https://doi.org/10.15201/hungeob-ull.65.2.2

Göndöcs, J., Breuer, H., Pongrácz, R., Bartholy, J., 2018: Projected changes in heat wave characteristics in the Carpathian Basin comparing different definitions. International Journal of Global Warming, 16(2): 119-135. https://doi.org/10.1504/IJGW.2018.10015777

Klysik, K., Fortuniak, K., 1999: Temporal and spatial characteristics of the urban heat island of Lódz, Poland. Atmospheric Environment, 33: 3885-3895. https://doi.org/10.1016/S1352-2310(99)00131-4

Lakatos, M., Bihari Z., 2011: A közelmúlt megfigyelt hőmérsékleti és csapadéktendenciái. In: Klímaváltozás - 2011, Klímaszcenáriók a Kárpát-medence térségére. (Szerk. Bartholy J., Bozó L., Haszpra L.), MTA és ELTE Meteorológiai Tanszék, Budapest. 146-169.

Oke, T.R. 1973: City size and the urban heat is-land. Atmospheric Environment, 7: 769-779. https://doi.org/10.1016/0004-6981(73)90140-6

Pongrácz, R., Bartholy, J., Dezső, Zs., 2010: Application of remotely sensed thermal information to urban climatology of Central European cities. Physics \& Chemistry of Earth, 35: 95-99. https://doi.org/10.1016/j.pce.2010.03.004

Schwarz, N., Lautenbach, S., Seppelt, S., 2011: Exploring indicators for quantifying surface urban heat islands of European cities with MODIS land surface temperature. Remote Sensing of Environment, 115: 3175-3186. https://doi.org/10.1016/j.rse.2011.07.003. 
Talamon, A., 2014: Alacsony energiafelhasználású épületek lehetőségei Magyarországon.

PhD értekezés, Debreceni Egyetem, Földtudományok Doktori Iskola, 146p.

Voogt, J.A., Oke, T.R., 2003: Thermal Remote Sensing of Urban Climates. Remote Sensing of Environment, 86: 370-384. https://doi.org/10.1016/S0034-4257(03)00079-8

\section{Internetes hivatkozások:}

157/2005. (VIII. 15.) Kormányrendelet a távhöszolgáltatásról szóló 2005. évi XVIII. törvény végrehajtásáról. https://net.jogtar.hu/jogszabaly?docid=A0500157.KOR

FÖTẢV, 2019: Üzemviteli megállapodás. http://www.fotav.hu/lakossagi-ugyfelek/kozoskepviseletek-kepviselok-reszere/uzemviteli-megallapodas

OMSz (Országos Meteorológiai Szolgálat): Éghajlati adatsorok 1901-2010 https://www.met.hu/eghajlat/magyarorszag_eghajlata/eghajlati adatsorok/

\section{ORCID}

Dian Cs. (D) https://orcid.org/0000-0001-9622-1884

Talamon A. (iD https://orcid.org/0000-0001-9783-0913

Pongrácz R. (iD https://orcid.org/0000-0001-7591-7989

Bartholy J. (D) https://orcid.org/0000-0002-3911-7981 